DOI: $10.21625 /$ resourceedings.v1i1.176

\title{
RISKS AND UNCERTAINTY IN THE FORMAL SOLUTIONS TO THE INFORMAL SETTLEMENTS IN INDIA
}

\author{
Doaa Ahmed Shehata Abouelmagd ${ }^{1}$ \\ ${ }^{1}$ Assistant Professor, Faculty of Fine Arts, Helwan University, Cairo, Egypt
}

\section{Keywords}

Formal solutions, informal settlements, Risks, India

\begin{abstract}
This paper discusses various formal solutions adopted by the Indian official bodies to deal with the Indian informal settlements "the slums". It focuses on Pradhan Mantri Awas Yojana (PMAY) or the "Housing for All by 2022" as an essential housing act toward improving the living conditions of the informal settlements, and to achieve cities and housing for all.

According to the Indian 2011 census, $66 \%$ of formal towns and cities in India have informal areas. Nearly one in every six urban Indian residents lives in a slum. Poor and rural immigrants find in the slums a physical shelter, but they lack the quality of living and basic social-economic infrastructure. Bringing a formal solution to the informal settlements is a challenge that requires a deep understanding of the Indian heterogeneous population.

This paper starts with the main housing policies that were launched in India during the 2000s and extend to cover several case studies in Indian cities based on a field visit conducted in India. It discusses several concepts applied such as in-situ and relocation alternatives; possible improvements for the local communities by promoting livelihood resources; the concepts of using land as a resource, land pooling and public-private partnership in developing the slums.
\end{abstract}

This paper aims to understand the notion of risks and uncertainty in these solutions as constraints in improving the informal settlements in India for a better urbanism future.

\section{Introduction}

Since the 1990s after Habitat-II in 1996, the majority of world nations adapted approaches to improve and develop their informal settlements by involving different actors (i.e. public sector, private developers, NGOs, international agencies). These approaches recognized the right of housing and habitat for the slums dwellers instead of the slums clearance agenda. The turning point happened in 2016, with the new urban agenda introduced with the Habitat-III, where the cities and urban entities are seen as a source of empowering and the habitat of a large number of the labors and source of economy; it lays out how cities should be planned and managed to best promote sustainable urbanization, and achieve livable cities. Habitat-III aims to reach the United Nations target of achieving improvements in the lives of at least 100 million slum dwellers by the year 2020, as part of the (MDGs ${ }^{1}$ — target 11) (UN-Habitat, 2016).

As a step towards its urban transformation, in 2015 India has joined UN Climate Summit in Paris in December 2015. Following, in 2016, India has introduced its National urban report that promotes reforms to what is necessary to take the Indian urbanization forward and achieve the MDGs - target 11. For example: Improving slums and governance, making municipalities fiscally robust, bringing in optimality in land use and land utilization, inclusive urban development and building capacities for making urbanization productive and inclusive (Gill HS., 2016).

\footnotetext{
${ }^{1}$ Millennium Development Goals
} 
This paper introduces several formal solutions provided by the Indian government to handle the slums' problems. The paper is organized into four sections; it starts with an introduction to the urbanization and population growth in the Indian cities, following it introduces the main national housing policies in India that were launched during the 2000s, leading the reader to reach the current major act of PMAY or the "Housing for All", in the third section the four vertical of the PMAY ${ }^{2}$ act are explained with examples from various cities, and discussion of concepts like land pooling and $\mathrm{FAR}^{3}$. In the last section, three NGOs are brought as examples for improving slums' dwellers livelihood and for upgrading the slums. Finally, the paper ends with final conclusion and recommendation.

Besides the literature review, the methodology used to collect data for this paper was based on the technical visits to different Indian States and municipalities cooperation, fieldstrips to housing projects and slums, interviews with dwellers, and lectures given by housing experts in India. These data were collected by the author as a part of the professional training program "Formal Solutions to Informal Settlements" conducted in India from 19th September 2016 to 28th October 2016, organized by the Human Settlement Management Institute (HSMI), and fully sponsored by The Ministry of External Affairs, Government of India under International Technical \& Economic Cooperation program (ITEC).

\section{Urbanization and Population Growth in India}

India is the biggest democratic system in the world based on the number of population; in 2013, the populations estimated to be 1.252 billion, living in 29 States. India is a decentralized federal system, the political systems dealing with the housing and urban issues consist of three levels: National, State, and local governments; while the National government formulates the acts and mission, the implementation and detailed plans are done by the States and local bodies. These multi-levels of governance consider a challenge for coordination between different stakeholders and in service delivery. India urban system consists of 7933 cities and towns of different population sizes, and a population of $31 \%$ of the total population (Census, 2011).

The urban population in India is increasing dramatically; inner migration, urban-urban migration, labor migration and marriage migration are taking place strongly, but 2011 census data shows that natural increase is now more than the all these types of migration. Moreover, an estimated 180 million rural people live next to India's 70 largest urban centers, a number that will increase to about 210 million by 2030 (INR, 2016:23 and Census, 2011).

In $2011,17 \%$ of the urban households were living in slums; the percentage has been reduced compared with 2001. However, the absolute number of households living in slums has increased from 10.15 million in 2001 to 13.75 million in 2011. The megacities of Greater Mumbai, Delhi and Kolkata house about 42 to $55 \%$ of their population in slums, the proportion of slum dwellers and urban poor in the million-plus cities is around 35\%(INR, 2016:94).

Census of India 2011, defines three types of slums (see fig. 1, 2, 3 and 4), these are notified, recognized and identified slums ${ }^{4}$. The formal city lays beside the informal parts in the Indian cities (see fig. 5), urban poor and slum dwellers in India constitute $25-65 \%$ of the city population; rarely occupying more than $3-5 \%$ of city landscape The growth and expand of the cities to include small villages on its periphery, creates hubs of informal settlements (Census of India 2011 and Mahavir U., 2016).

\footnotetext{
${ }^{2}$ Pradhan Mantri Awas Yojana

${ }^{3}$ Floor Area Ratio

${ }^{4}$ Census of India define the slums as following: Notified slums: "All notified areas in a town or city notified as 'Slum' by State, Union territories Administration or Local Govern Government under any Act including a 'Slum Act' may be considered as Notified slums". (Census of India, 2011).

Recognized slums: “All areas recognized as 'Slum' by State, Union territories Administration or Local Government, Housing and Slum Boards, which may have not been formally notified as slum under any act may be considered as Recognized slums" (Census of India, 2011). Identified slums: "A compact area of at least 300 population or about 60-70 households of poorly built congested tenements, in unhygienic environment usually with inadequate infrastructure and lacking in proper sanitary and drinking water facilities. Such areas should be identified personally by the Charge Officer and also inspected by an officer nominated by Directorate of Census Operations. This fact must be duly recorded in the charge register" (Census of India, 2011).
} 

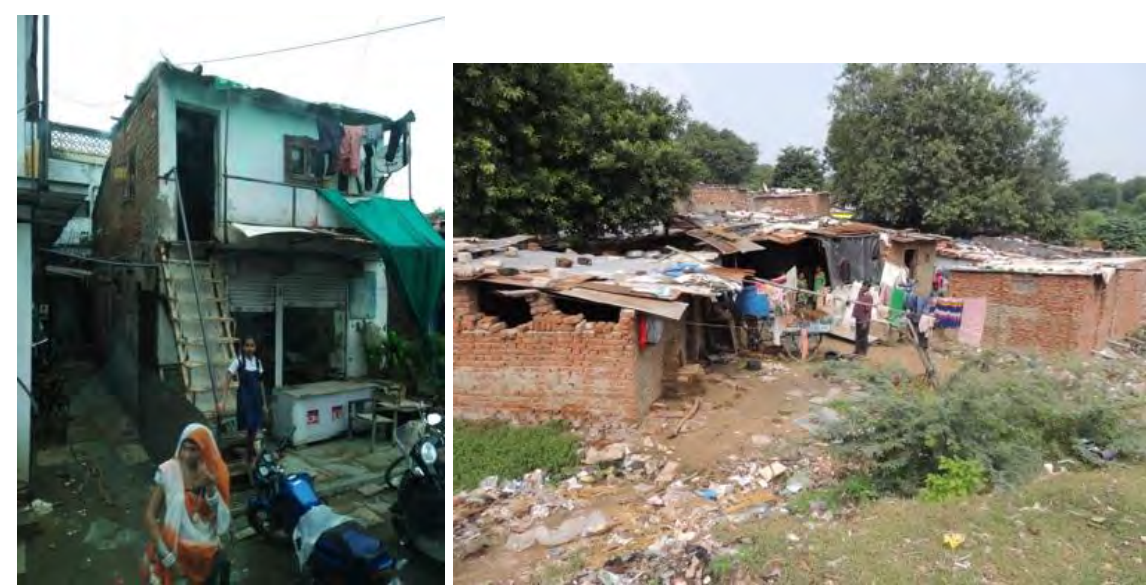

Fig. (1) and (2): slums in Slums in Ahmedabad; Source: photos taken by the author
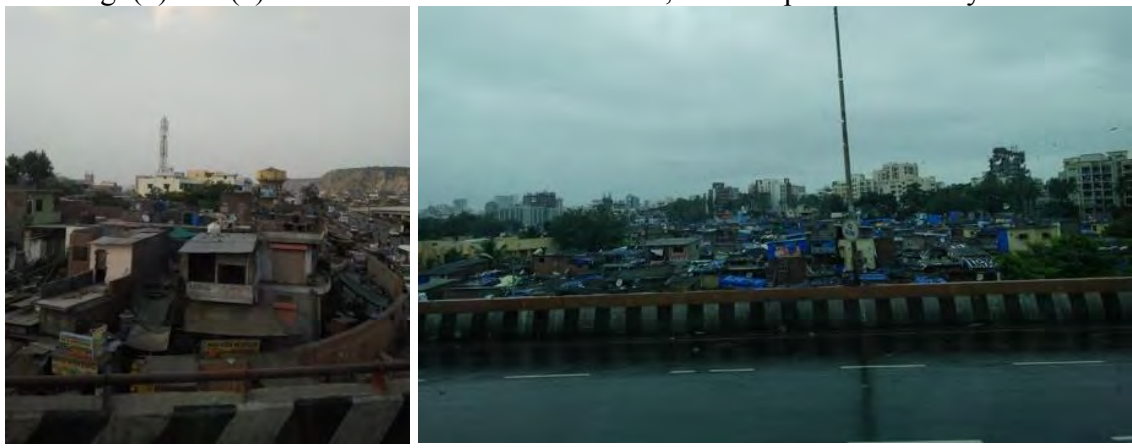

Fig. (3) and (4): respectively slums in Jaipur and Mumbai Source: photos taken by the author

Every State follows its own legislation for defining a slum. However, the key characteristics in all the definitions are dilapidation, overcrowding, faulty layout, lack of ventilation, and inadequate availability of basic services such as water, sanitation, and drainage (INR, 2016:81).

On the other hand, $92 \%$ of India's total workforce, the seventh growth economy in the world, live in slums, in which $98 \%$ work in enterprise and micro business and have no social security; the informal economy plays an important role in the formal economy growth of the country, big cities cannot survive without its informal sector, for example during the commonwealth games the informal transportation system played the role in moving inside the city of Delhi. India is also ranked number 130/188 in the Human developed Index (HDI), inequality in terms of source distributions, and social exclusion are essential parts of the slum equation. Slums are not the house of only the Indian poor, but also, seasonal workers, labor immigrants, and middle and low middle classes especially in cities like Mumbai and Delhi, where the land value and houses prices are very high (Jain, 2016:2; HDI, 2015; knoema, 2016).

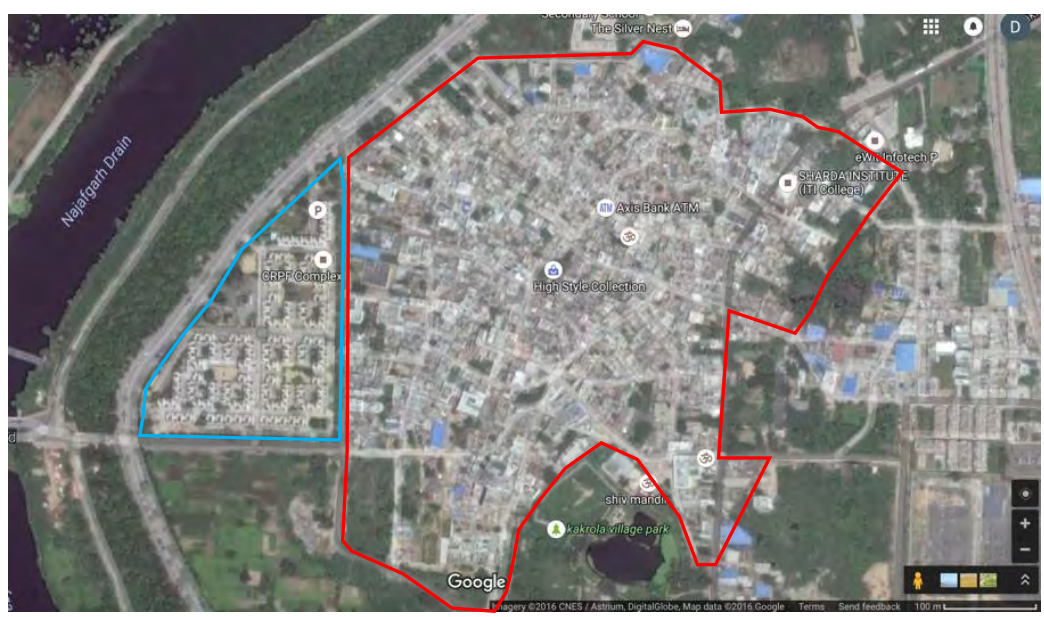

Fig. (5) the formal city vs. the informal in Delhi, Case of Kakrola village Source: modified from google earth 


\section{National Policies Dealing with Slums}

Since its independence, India has launched many housing acts and missions to deal with the slums, unfortunately, these programs failed to stop slums growth. Different acts were launched since the beginning of the 2000s and different models are adopted in the different States to rehabilitate and develop the slums, in this section the main acts that affected urban India since the beginning of 2000 are explained.

In 2005, Jawaharlal Nehru National Urban Renewal Mission (JNNURM) was launched as the first real call to deal with the slums. it focused on the Indian cities aiming at creating economically productive, efficient, and responsive cities by a strategy of upgrading the social and economic infrastructure. The main program under this mission is BSUP $^{5}$ that aims to provide slums with the basic infrastructure; the mission also aims to strengthen municipal governance. It is the first mission that combined solutions for slums and the provision of housing together. This mission was initially launched for a period of seven years, but it had three extensions and will be officially finished in 2017. One of the reasons that the mission was not completed on time was the change of the national government and the differences in the political views between the three administrative levels dealing with the slums (National, state, and local governments). Other factors caused the delay includes the lack of litigation-free land, inconsistencies between the beneficiaries, delay in financial closure and cost escalation. Unfortunately, some projects were delayed with consequent time and cost overruns (JNNURM, 2005; and India Press Information Bureau, 2015).

In 2007, National Urban Housing and Habitat Policy (NUHHP) was launched, the ultimate goal as a state in the policy was: "to ensure sustainable development of all urban human settlements duly serviced by basic civic amenities for ensuring a better quality of life for all urban citizens" (NUHHP, 2007).

It stimulates the development of both rural \& urban areas, provides affordable housing to EWS \& LIG $^{6}$, provide financial concerns for housing \& infrastructure, promote cost-effective building materials \& technologies, and upgrading slums. The policy suggests to develop degraded lands unsuitable for agriculture but linked to the existing large cities The NUHHP affected in many States but did not affect the Indian housing situation as much as the previous JNNURM and the following RAY schema. It also required the states to develop their housing policies using a bottomup approach, in 2016 only eleven States were formulated housing policies (Singh D., et al., 2013; and NUHHP, 2007).

In 2011, Slum-free India through the Rajiv Awas Yojana (RAY) schema was launched as a policy under the JNNURM to bring existing slums within the formal system, undertake the shortages of urban land and housing that keep shelter out of reach of the urban poor, bring legal solutions that keeps the sources of livelihood and employment of the poor, and finally empower slum dwellers with house ownership. In this schema a GIS and MIS ${ }^{7}$ were conducted by the Indian States to map all the slums, the slums' dwellers were given the right to stay on the same location after development or to be relocated within a distance not more of 3-5 km away from their original settlement. In the past, the relocation used to take place $15-20 \mathrm{~km}$ away and most of the dwellers used to go back to live in the slums to keep their livelihood assets (RAY, 2013).

The mission had two phases, the preparatory phase for a period of two years, which ended in June 2013, the second phase was approved for implementation in the period of 2013-2017. RAY developed projects with strong community participation, created new models of PPP whereby the private sector can be encouraged to take up affordable housing for the EWS/LIG (RAY 2013 and Mahavir U., 2016).

But, not all the States finished the GIS and MIS of the slums, technical problems faced the states, issues in educating and training professionals were faced. There is no clear plan for the update of the database; some collected data lack the creditability as some slums are only accessible through their community leaders and the given information is that given by them. In 2015, the RAY and with the change of the national government, the program came under the PMAY.

The current major act dealing with the slums is the Indian Prime minister call in 2015 to construct 20 million housing units by 2022 and achieve housing for all; through Pradhan Mantri Awas Yojana (PMAY) or the "Housing for All by 2022". It addresses the housing requirements of the urban poor; it deals with the slum problems and provides affordable housing for the poor. Under this act each Indian has the right to live in an adequate house with a private toilet, it composes of four main verticals (see fig. 6).

\footnotetext{
${ }^{5}$ Basic Services to Urban Poor

${ }^{6}$ EWS (economically weak sections) and LIG (low income groups

${ }^{7}$ Management Information system
} 


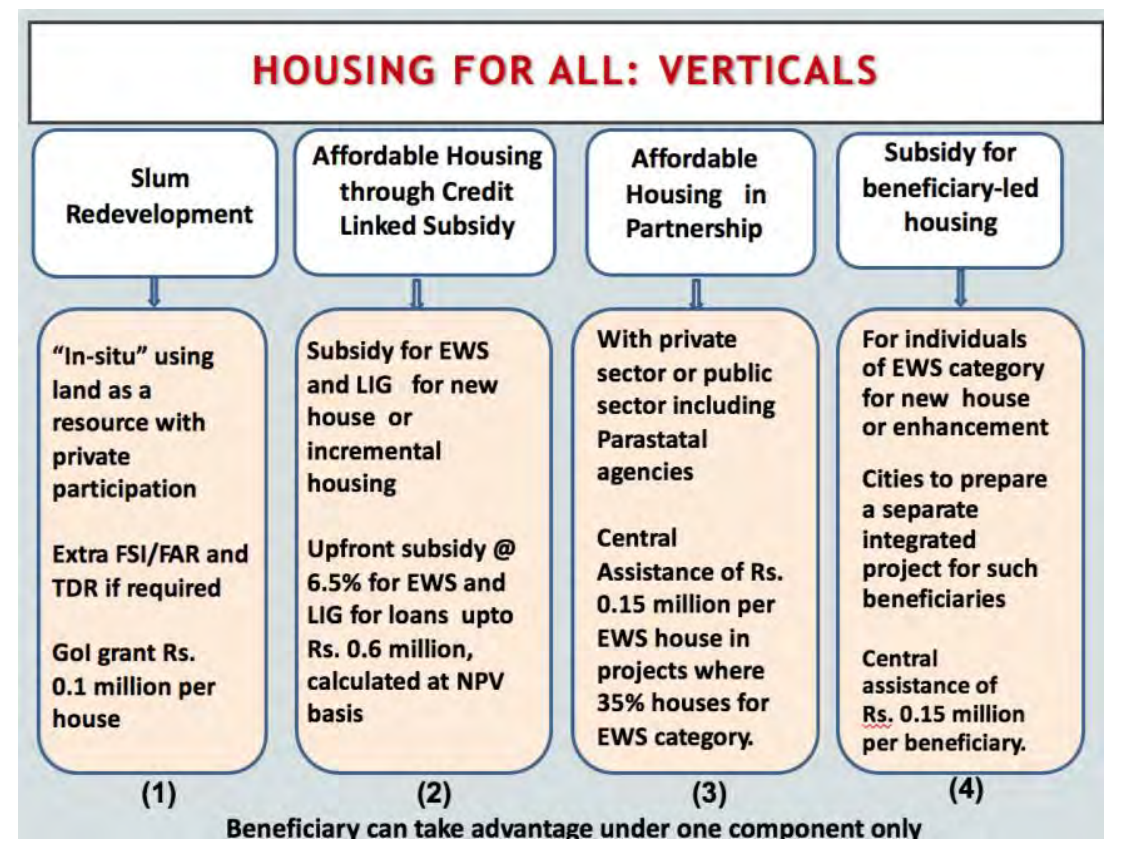

Fig. (6), The four verticals of the PMAY program Source: (PMAY, 2015)

The act contains all remaining projects started under (JNNURM) and (RAY). It developed National option of in-situ slum redevelopment using land as a resource with the participation of private developers. A grant of INR 100,000 per eligible slum dweller is provided by the Government of India, using land as a resource and regulation for in-situ development are left to be formulated by States/UTs ${ }^{9}$ as per their policy (INR, 2016:83). There are another 15 million units that need to be improved and upgraded, and there are 11 million vacant units in India that are not affordable for the urban poor (Jain, 2016:4).

The PMAY proposes a dwelling unit averaged $30 \mathrm{sqm}^{10}$ for the EWS and $60 \mathrm{sqm}$ for the LIG, it also aims to rehabilitate 65 million slum dwellers in a period of seven years (Jain, 2016:1).

To guarantee that the beneficiaries can only benefit from any subsidized project in India only once, an Aadhaar verification Number ${ }^{11}$ was found by the Indian government. No resident can have a duplicate number since it is linked to their individual biometrics; thereby it is identifying fake identities, In the past, records show that beneficiaries used to get benefit from more than one schema more than one time in the same or in different States. Another important concern that the ownership of the dwelling unit is in the name of a female or in a shared ownership between male and female. This is to guarantee the house ownership for the family (GOI, 2016).

\subsection{PMAY, "Housing for All"}

In this section, the four verticals of the PMAY "Housing for All" will be explained:

\section{Options for In-situ and Relocation of the slums}

After the failure of the relocation of the slums dwellers far away from the city center and their livelihood, the Indian government is applying the in-situ development as a first component of the PMAY act. But, such act is mainly possible for the slums constructed on public lands ${ }^{12}$. Moreover, private developers who play an essential role in this development are only attracted to develop slums located on high-value land applying the FAR ${ }^{13}$ to gain extra profit. The in-situ development is very successful to maintain the livelihood of the inhabitants who mostly work near the slums. It is also essential to mention that most of the Indian States have been recently relocated not more than 3-5 km far away from their original slum.

\footnotetext{
${ }^{8}$ India rubies

${ }^{9}$ Urban territory

${ }^{10}$ Square meter

${ }^{11}$ Aadhaar, which means "foundation" in many Indian languages, is the term for the unique identity number issued by the UIDAI. Savings from eliminating duplicates and fakes through Aadhaar-based identification will further enable governments to expand benefits to other eli-gible residents (Government of India, 2016).

${ }^{12}$ A further discussion of slums located on private lands will be take place later

${ }^{13}$ Floor Area Ratio
} 
There are different models of in-situ and relocation development depending on the by states/UTs, these models target the involvement of the private developers, it also includes public and State agencies, NGOs, banks, microfinance institutions $\mathrm{CBOs}^{14}$.

As the PMAY was recently launched there is no complete example that can be evaluated, and as mentioned before all the previous acts are now continuing under the PMAY housing for all. Examples explained in this sections were visited by the author during the professional training held in India and were constructed under previous schemas of (JNNURM) and (RAY), they show how the PMAY housing act developed options for In-situ and relocation of the slums and shows the future of this act.

PMAY act guidelines, declare the that the States/UTs select private developers through an open transparent bidding process; financial and non-financial incentives, concessions, and contributions from the beneficiaries/ slum dwellers if any, are to be integrated in the project and declared "a priori" in the bid document for the prospective developers, developers complete and finish the project using its financial and technical resources as mandated by the implementing agency; States and cities may provide additional FAR/FSI ${ }^{15}$, allow mixed or commercial use, and relax density and other planning norms for making the projects financially viable (INR, 2016: 89).

It is up to each State/UTs to decide the type and parentage of the contribution of the slums' dwellers in each project and whether it will be an owned property or a renewable, mortgage or inherited leasehold. In the projects visited by the authors during the technical visits, the slum' dwellers paid 10\%-20\% of the new formal dwelling unit under ownership hold. The rest is paid by loans taken from banks with low-interest rates and repaid over the duration of 20 years (Jain, 2016: 29 and technical site visits in India).

As stated in the INR: 2016, any slum rehabilitation project under this component is composed by two parts, a slum rehabilitation part which will be used for providing housing and basic civic infrastructure to eligible slum dwellers and a free market sale part, which is available to developers for selling in the market so as to cross-subsidize the project (INR, 2016:83).

The slums dwellers are relocated in a transitional housing not far from the original settlement until the completion of the project, or are given a monthly compensation so they can rent a dwelling in the private market. A lottery System exists to distribute the new dwellings with a preference to those with disability challenges and elders to take the ground and first floors units.

\section{In-situ Developing through PPP ${ }^{16}$ as stated by $\mathrm{SRA}^{17}$ in Mumbai, Maharashtra State (2016):}

A successful example is introduced by the Government of Maharashtra; it is considered one of the advanced states in India in dealing with the rehabilitation of the slums. Mumbai the Capital of the state is the home of one of the largest slums in the world Dharavi ${ }^{18}$; It is also estimated that more than 55\% of Mumbai's population stays in slums. In 1995, the State has introduced a nodal agency for the Slum Rehabilitation and the Slum Rehabilitation Authority (SRA) was found. SRA brought a Slum Rehabilitation Program that analyzes and reviews existing positions of slum areas in the city and manages the rehabilitation and development of these slums (Naiknavare developers, 2016).

Comparing with other cities in the same State, the SRA in Mumbai succeeded in introducing PPP in developing the slums located on public lands as the economic value of the land in Mumbai is high. Another example in Maharashtra is Thane city located $30 \mathrm{~km}$ far away from Mumbai, only in 2014 the Mumbai slum rehabilitation model was reintroduced in Thane (see fig. 7 and 8) (Ashar, S., 2014).

\footnotetext{
${ }^{14}$ community based organizations

${ }^{15}$ The floor area ratio (F.A.R.) is the principal bulk regulation controlling the size of buildings. F.A.R. is the ratio of total building floor area to the area of the plot (taken from: Govt. of Ker-ala, 2016). It should be note here that FAR and FSI (Floor Space Index) refer to the same meaning.

${ }^{16}$ Public Private Partnership

${ }^{17}$ Slum Rehabilitation Authority

${ }^{18}$ It is located on the northernmost tip of Mumbai island City, was the home of the Koli fishing community and the Mahim Creek was their source of fish and livelihood for centuries (SRA, 2016).
} 


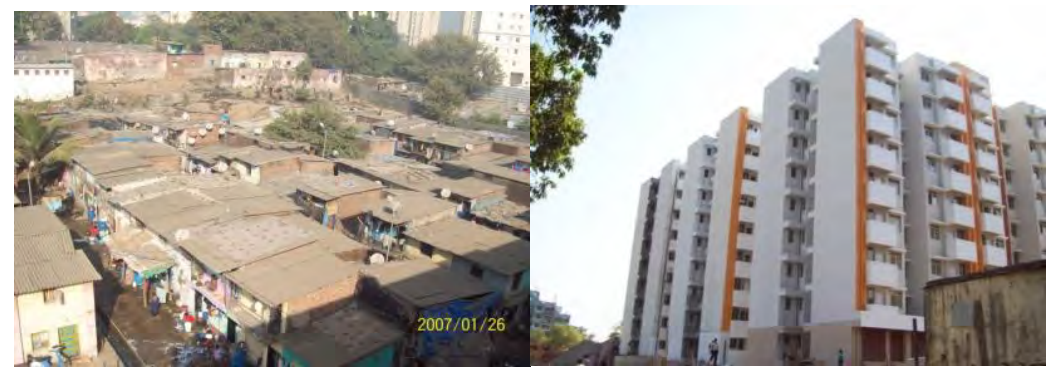

Fig. (7) and (8), In-situ development project by the State in Thane, Maharashtra State Source: photos by Thane SRA

\section{The process of in-situ development in Mumbai is described as following:}

At least $70 \%$ of the slum dwellers unite under a slum dwellers co-operative housing society; they appoint a chief promoter; the co-operative collects share capital of $50 \mathrm{Rs}^{19}$ per member. This is then deposited in the name of the proposed housing society in the Mumbai district central co-operative/ Maharashtra State co-operative bank ltd.

The slum dweller cooperative collects documents regarding the ownership of the land (in case of private land ownership), then the land is measured and the structures are defined. A database with the name of occupants and a numbered plan with their houses numbers is prepared. A suitable developer is chosen after the open transparent bidding process, he appoints professionals like architect/ licensed surveyor; structural engineer; etc. The developer enters into individual agreements with all the slum dwellers agreeing to participate in the scheme. A proposal enclosing requisite plans; annexures and documents are submitted by the professional to SRA for final approval (see fig. 9 and 10 for a rehabilitation of a slum by a private develop) (SRA, 2016).

Interviews conducted by the author with the inhabitants of one selected project shows that they are pleased and satisfied with the project comparing with their previous conditions in the slum. But it should be mentioned here that interviewees cannot be classified under LIG or WES. The high price of the residences in Mumbai led middle and low middle class to live in the slums. The building contains a community place and a kindergarten on the ground floor (Technical field trip visit to Mumbai).

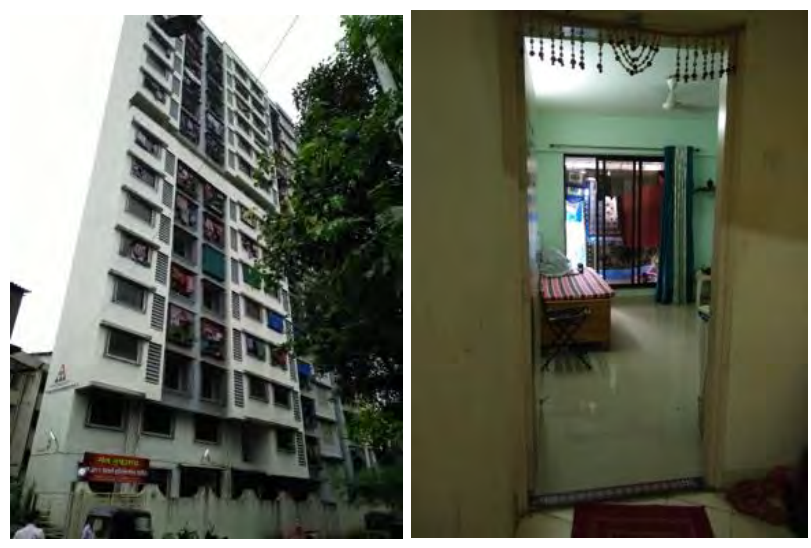

Fig. (9) and (10), In-situ development project by a private developer in Mumbai, Maharashtra, photos show the building and a view of an apartment Source: Photos by the author

\section{In-situ and relocation development by Public Authority in Jaipur, Rajasthan State:}

Information collected from Jaipur municipality concludes that all the projects before the PMAY were funded by the State. An example is the BSUP project "Jaisighpura Khor" (see fig. 11), the project was completed under BSUP in JNNURM schema. It is located $5 \mathrm{~km}$ away from the original slum settlement and $12 \mathrm{~km}$ from Jaipur city center, Although the project meets the maximum distance of the relocation of the slum, it is far from the city center. Several governmental organizations are responsible for the project as a result, the housing project is completed but economic and social services such as schools, health center, public transportations still not established yet which raise questions about the future livelihood of the residents (see fig. 12).

Only $30 \%$ of the inhabitants were relocated in the project by October 2016 . Each dweller pays $10 \%$ of the total cost of the unit with a bank loan guaranteed by the new housing units. When the project is fully occupied the community

\footnotetext{
${ }^{19}$ Rubies
} 
must establish a community board to take care of the maintenance of the project. The carpet area of each unit is 25 sqm. Interviews with the inhabitants reflect their satisfaction with the project, but it is early to judge especially that the project is not fully occupied (Technical field trip visit to Jaipur).
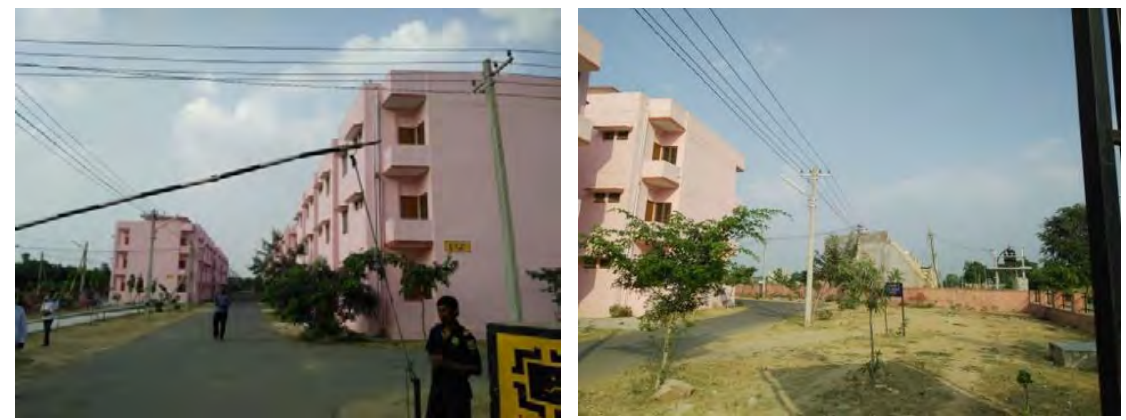

Fig. (11) and (12), BSUP project and the empty piece of land dedicated to the school, Jaisighpura Khor, Delhi Road Jaipur, Rajasthan Source: Photos by the Author

\section{In- Situ and relocation development by Public Authority in Ahmedabad, Gujarat State:}

Gujarat is one of the advanced States in dealing with slums, it is worth to mention that the current India Prime Minister Narendra Modi was the chief minister of Gujarat between 2001-2014; the notion of the housing for all PMAY act is his experience in dealing with the slums in Gujarat. One of the distinctive projects of this State is the development of Sabarmati river that took place between 2005-2014 aiming to achieve environmental improvement, social infrastructure and sustainable development for the river. The project presents a brilliant example of how can a slum development change the image of a city (see fig. 13 and fig.14). During the dry seasons, the river banks were places for farming. With time it also offered a place for various informal economic activities and the river banks were squatted by 10,000 households living in slums that lacked basic infrastructure; untreated sewage flowed to the river and dumping of industrial waste posed a major health and environmental hazard. The river was inaccessible and it became a virtual divide between the two parts of the city (Sabarmati River Front Development Corporation, 2016a).
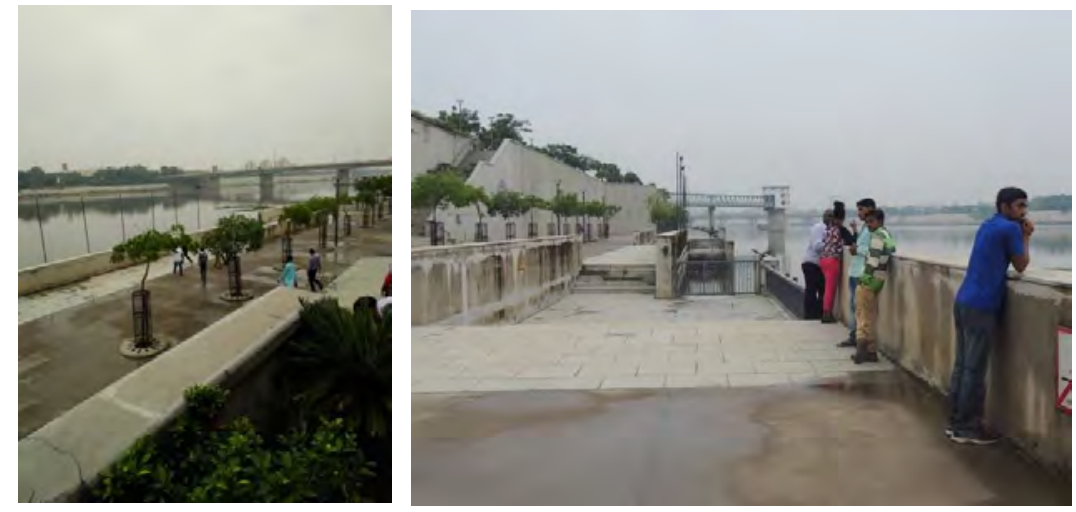

Fig. (13) and (14) Sabarmati river project in Ahmedabad, Source: photos by the author

Slum dwellers affected by the project have been relocated and provided with permanent housing with secured tenure in many relocation sites interspersed within the city's boundaries has been carried out under the supervision of the Gujarat High Court; the resettlement areas were very much in the prime locations in the city and not far away in the periphery, the carpet area of each unit is $26.77 \mathrm{sqm}$. The river banks were transferred to accessible open public spaces for all the sectors of the community, location for private investors is also available, a fast metro will connect the city with the airport through the river banks (Sabarmati River Front Development Corporation, 2016b).

The project also aims at integrating the informal activities such as laundering of clothes and informal markets. For example, the weekly flea market 'Ravivari' held every Sunday has been relocated to a site adjacent to its original location where specially designed vending platforms and designated areas for mobile vendors have been created (Sabarmati River Front Development Corporation, 2016a).

\section{In- Situ and relocation development by Public Authority in Bhopal, Madhya Pradesh State:}

Like the previously mentioned States, Madhya Pradesh State has applied in-situ development since 2005 with the JNNURM schema, but after visits to several projects, it can conclude that these projects have some hygiene and safety problems as shown in fig. 15 and 16. Another remark from the field visits, that only in Bhopal, the EWS projects were designed to have free spaces to park Toktok and motorcycles on the ground floor, which positively reach the resident's needs. 

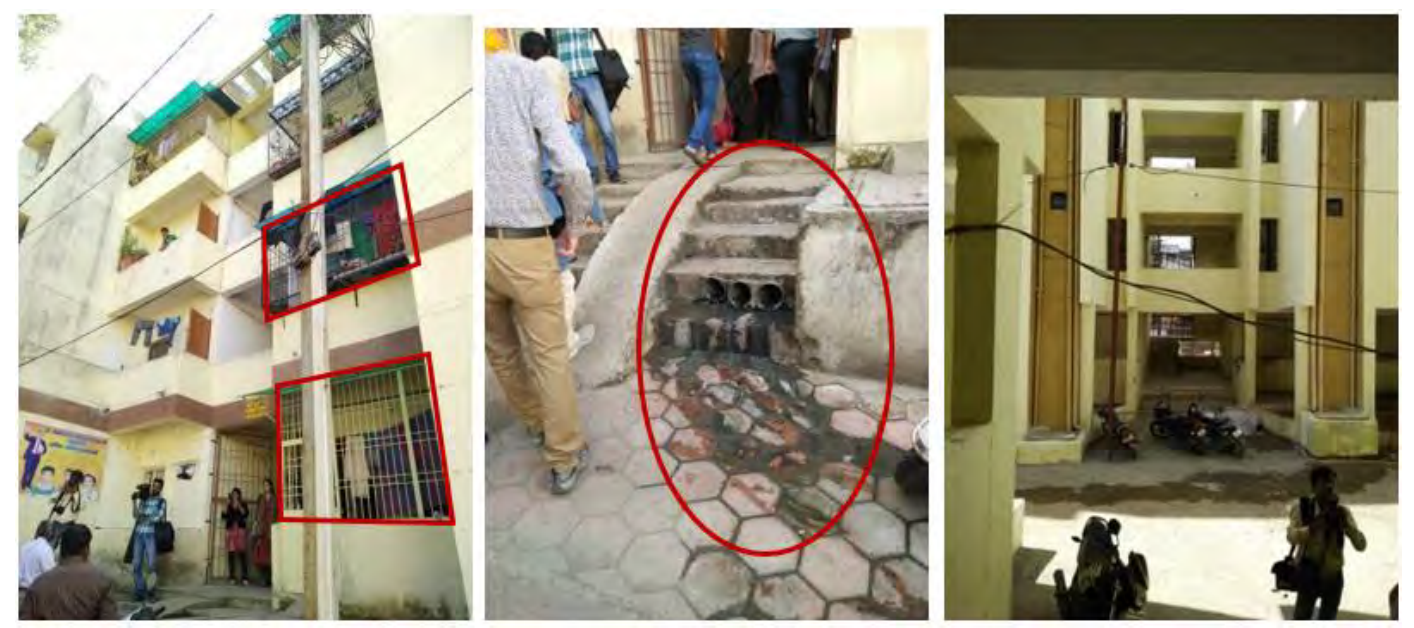

Fig. (15) and (16), Bhopal Rahul Nagar project under BSUP schema,

Fig. (17) Ambedkar Nagar Project under BSUP schema, Bhopal Source: Photos by the author

\subsubsection{Challenges in using land as a resource}

The land value plays an important role in the development of the slums. Slums located on low-value land, especially in the periphery lack the interest of the private developers. Therefore, even in the most successful example of Mumbai between 1995-2014, only $13 \%$ of the listed projects have been completed in an 18 years' period by the SRA (Ashar, S., 2014).

These have left the responsibility of development on the State governments as shown in the previous examples in Rajasthan, Ahmedabad and Madhya Pradesh. Hopefully, with the PMAY act, State governments can develop models to attract the private developers to play a better role in the development of the slums.

Another massive problem in using this concept is the when slum is located in a private ownership property. In the Indian national level, $44-48 \%$ of all notified slums and $41 \%$ of non-notified slums are located on private land (Jain, 2016:21). To develop a slum located on a private land, collecting documents regarding the ownership of the land and to get the owners and the community agreement for development consider enormous constraints. It is also essential to mention here that as many other slums in the worlds, slums' landlords exist also in India, and they can control the slum dwellers and official excitability for information.

\subsubsection{Challenges in using Floor Area Ration (FAR)}

One of the methods to attract private developers to develop slums is to give them high FAR Furthermore, higher densities with more floors can help in creating more buildings, house more people and gain more profit, but on the other hand, it creates social problems and unbalanced openness to build spaces. The balance between land use and density should be taken into consideration (Jain, 2016:7).

Technical site visits to project sites shows that the building heights are high in cities like Mumbai with G+20, medium in Ahmedabad with G+5 (see fig. 18) and low in Bhopal and Jaipur with G+3 and G+2 respectively. Interviews with residents in Mumbai shows that the residents do not have a problem in living in higher floor, in contrast with residents in Bhopal, Ahmedabad, and Thane who found it difficult and prefer the lower floors. 


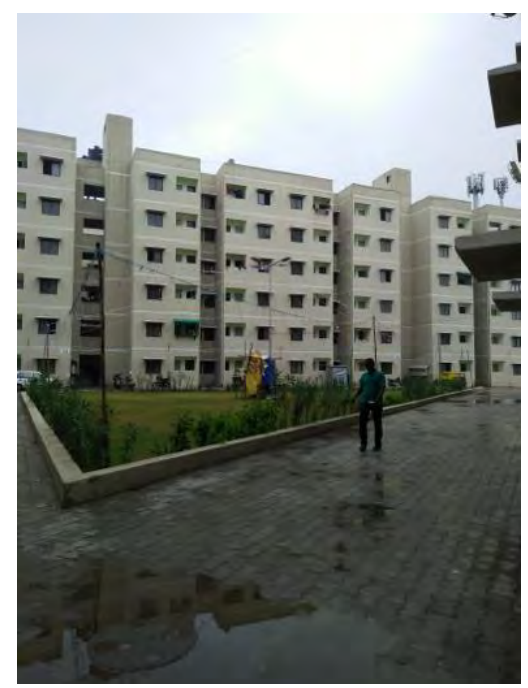

Fig. (18), EWS housing projects for slum dwellers at Vadaj, Ahmedabad Source: photo by the author

\subsubsection{Affordable housing through Credit Linked Subsidized Schema}

The second component in the PMAY program is CLSS (Credit Linked Subsidized Schema):

This component aims to expand the flow of home loans used in construction and acquisition of homes to the urban poor (EWS and LIG); with an interest subsidy at the rate of $6.5 \%$ in comparison to $9 \%$ if they got it from the other banks, for a duration of 15 years for a maximum amount of 600.000 Rs per each beneficiary (Jain, 2016:31).

Housing and Urban Development Cooperation $\left(\mathrm{HUDCO}^{20}\right)$ and National Housing Bank (NHB) have been identified as key agencies to channel the subsidize to the leading insinuations and monitor the progress of the components. Since its foundation in 1985, HUDCO has helped 17 million families to have a formal housing, in the last 10 years, one million units were provided for the poor.

\subsubsection{Affordable housing through PPP}

The third component of PMAY is to provide Affordable housing through PPP to increase the availability of housing for the EWS with a carpet area of $30 \mathrm{sqm}$, the States provide financial assistance to EWS houses built by a different partnership with States/UTs/Cities through its agents or with the private sector. A selling price for the units will be limited to a ceiling price affordable for the EWS groups.

The affordable housing project can be a mix of housing for different categories, with $35 \%$ of the project directed to the EWS; selected beneficiary should fulfill the "Housing for All" regulations (Jain, 2016: 32,33).

Jaipur cooperation municipality gives examples of how to attract the private developers to construct houses for the EWS \& LIG groups. This includes an obliged quota to be developed for the EWS \& LIG when any land is developed by private developers; encouragement to be awarded for the private developers when constructing houses for the EWS \& LIG like reduction in taxation, duties or even giving extra FAR for their other projects; giving a land free of charge to be developed by the private developers with restriction that $75 \%$ is developed for the EWS \& LIG and $25 \%$ for the higher income groups (Meeting with Jaipur Co. Municipality).

In Ahmedabad, Bhopal, Thane, Jaipur, and Mumbai, shortage of public land near the city centers resulted that the possible locations for the affordable housing are mostly located in the periphery of these cities which can bring future problems for the livelihoods of the inhabitants (see fig. 19 for Affordable housing through PPP in Bhopal city). These States are also developing models to attract the private sector to play a role in this vertical (meeting and presentations held in Co. Municipalities of Ahmedabad, Bhopal, Jaipur, Thane, and Mumbai).

\footnotetext{
${ }^{20}$ The Housing and Urban Development Corporation Limited (HUDCO) is a government owned cooperation in India. it is under the administrative control of the Ministry of Housing and urban alleviation. It is mandated with building affordable housing and carrying out urban development.
} 


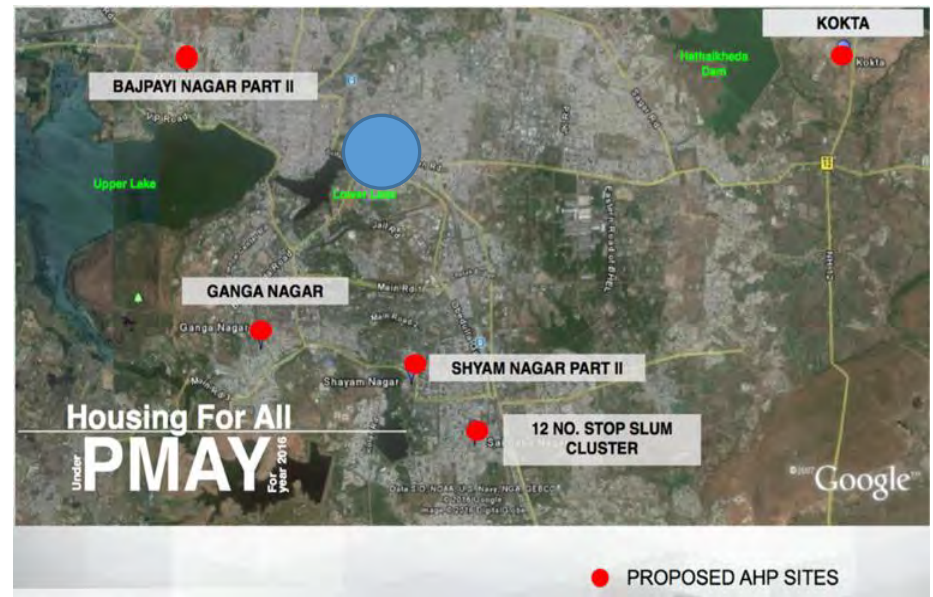

Fig. (19), proposed location for affordable housing projects in Bhopal in relation to the city center Source: Bhopal Municipality Co.

\subsubsection{Land pooling ${ }^{21}$ in Delhi}

Land pooling policy was approved in 2015, in Delhi, it brings the private sector as a main housing developer of the city; a major part of Delhi master plan 2021 would be developed/executed through this policy; rural fingers and villages located in the periphery of Delhi will be developed through this policy. But on the other hand, the developers since the approval of the policy and new urban boundaries have been busy buying lands from farmers across the 95 villages that fall under the purview of the policy; resulting in a sharp rise of land prices across these villages. Residential Floor Area Ratio (FAR) of 400 for Group Housing is available on the net residential land under the land pooling this will lead to promote vertical growth; $15 \%$ FAR is reserved for the (EWS) housing as affordable housing through PPP (Delhi Smart City, 2016; Narayan, S.; and Singh, H., 2015).

\subsubsection{Subsidize for individual leads housing constructions}

The fourth and last component of the PMAY act is directed to help the EWS individuals or families to apply for loans to construct or enhance their private houses located either in slums or outside the slums. The beneficiaries are those who cannot take advantages of the other PMAY other verticals, and they should fulfill the act requirements. One of the main requirements is the ownership of the land by the beneficiary and the condition of the house in case of enhancing. ULB ${ }^{22}$ and States should prepare an integrated citywide housing project with the city development plan to ensure the construction of the houses within the planning regulations. Projects should be approved by the States that should ensure the required financial resources from the individual themselves, the Government of India, the State government assistance (Jain, 2016: 34,35).

\section{Possible improvements for the local communities by promoting livelihood resources through PPP for upgrading informal settlements}

In this section, three nonprofit initiatives are presented to highlight the role and importance of the NGOs in improving the livelihood of the local communities and upgrading the slums. The first example presents the Role of livelihoods in urban revitalization through the case of Hazrat Nizamuddin Dargah, the second presents the role of empowering women in developing the slums through SEWA organization, the last one is an example CURE organization that link the urban poor with the urban development of their city with a special focus on their role in solving the sanitation problem. Although the three examples are exceptional, there is a need for more NGOs to work on the improvements for the poor communities in India.

\subsection{Agakhan: Role of livelihoods in urban revitalization: A case of Hazrat Nizamuddin Dargah (Delhi)}

This project presents a non-profit PPP; the conservation was completed by the Aga Khan Trust for Culture, with cofunding from the TATA Trusts and the Archaeological Survey of India. It presents an example of the first PPP at any of India's World Heritage Sites. The project addresses heritage conservation (see fig. 20), socio-economic

\footnotetext{
${ }^{21}$ Under the land pooling policy in India, landowners can pool their land for development, instead of compensation, the owners will get part of the land back after the authority has set up the infrastructure. After the developer hand over his land, he may not get same land after development. Instead, he will get land within $5 \mathrm{~km}$ radius of original location of the land equally in value to the original land (IRX Live, 2016; Nagpal and Bureau, 2015)
}

\footnotetext{
${ }^{22}$ Urban local bodies
} 
development, environmental development, urban planning, culture revival in the Indian urban context of a densely populated historic district Delhi.

Besides the heritage conservation, the poor community is supported by four initiatives: early childhood care \& development, elementary and adolescent education, and finally livelihood Programs. The elementary school has been improved through its infrastructure, curriculum, classroom processes and better engagement with the community through the school management committee. A medical care was improved through the health care programs and the clinic. Other programs were provided for the community members such as vocational education, computer and IT training, skill training and engagement of women in areas like retail, hospitality, construction and associated trades, and finally crafts. Moreover, improvement of open and public spaces took place and a community toilet was provided (see fig. 21 and 22) (Agakhan, 2015).

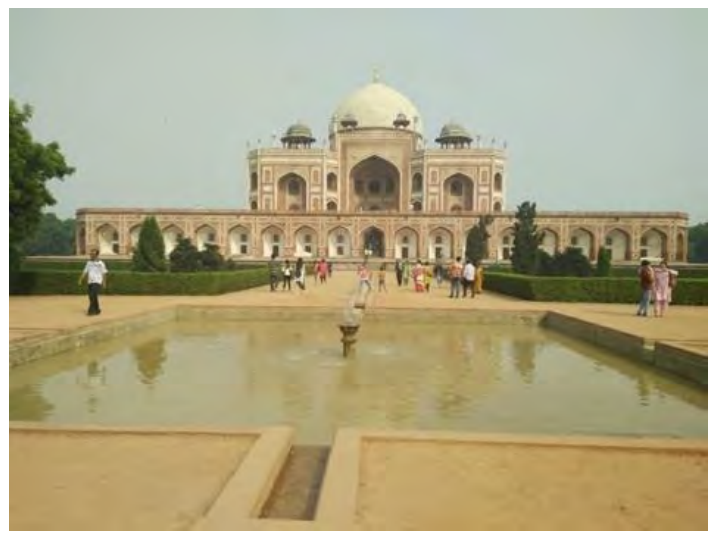

Fig. (20) Hymayum tomb,
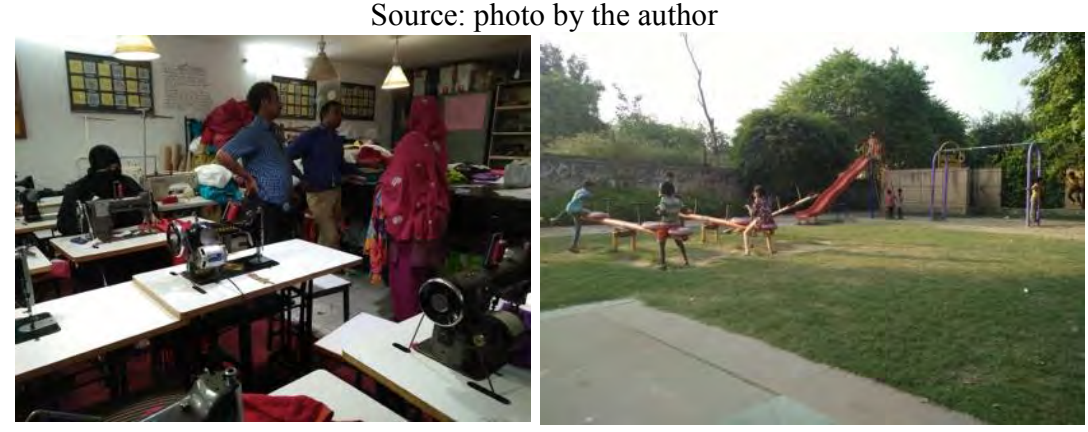

Fig. (21) and (22), the urban and social, economic development in Nazrat Nizamuddin Basti through handcrafts and improving public spaces

Source: photos by the author

\subsection{SEWA Self Employed Women's Association (Ahmedabad)}

SEWA is an organization of poor and self-employed women workers who do not have a stable job and run selfbusiness. SEWA's main goals are to organize women workers for full employment; as part of supporting women SEWA provides financial and technical support for women's housing and enable access to services and land rights, microfinance loans are also provided to support the livelihood of the women (SEWA,2016).

An example of SEWA initiatives in developing the slums is the role of the NGO with the community members of Kailashnagar, Sabarmati in Ahmedabad (see fig. 23 for comparison of phase one and the remaining part of the slum). 


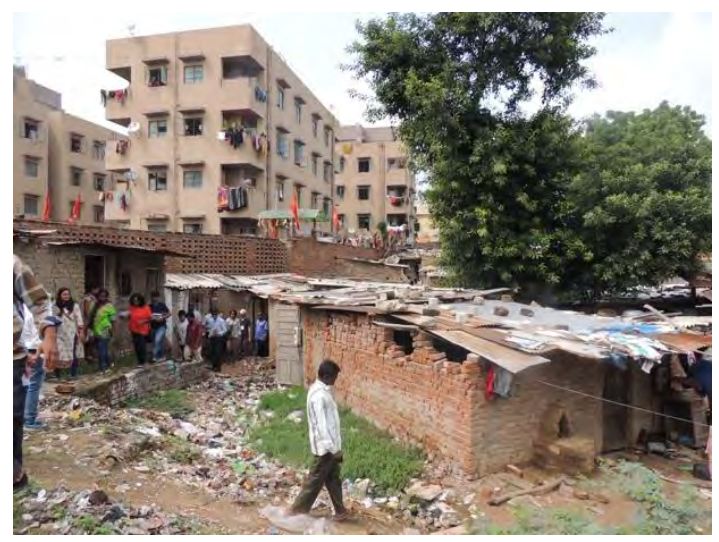

Fig. (23), The in-situ development Vs. the slums, Kailashnagar, Sabarmati in Ahmedabad Source: photo by the author

SEWA initiated series of meetings with community members, conducted a survey, obtained the consent of beneficiaries, verifications etc., among 220 eligible households \& 1 shop holder. For development purpose, SEWA also initiated meetings with the developer who has completed phase I of the project comprising of 67 dwelling units with all infrastructure facilities and allotted to the beneficiaries. The role of the NGO still in progress with the rest of the community who seek the development of the rest of the slum. The new dwellings are given free of charge for the beneficiaries, in exchange the developer will get part of the land free of charge to develop a private project (Data collected from the visit to SEWA NGO).

\subsection{Centre for Urban and Regional Excellence (CURE)}

CURE is a not-for-profit development organization working with urban informal and low-income communities in several States inside and outside India; it provides innovated solution to link the urban poor with the urban development of their city. Five main components distinguish this organization that applies PPP: dealing with the sanitation problems, building sustainable livelihood of the poor with heritage sites, providing social and economic housing services, slums development, and finally water supply and rain harvest projects (CUREINDIA, 2016).

An example of the CURE projects is: Savda Ghevra, Delhi, the slum community have been challenged by the lack of water and sewer infrastructure in their area. CURE has built a shared closed-loop sanitation system a cluster septic tank (CST) for 322 households living in the slums. The CST is networked to home toilets through simple sewer lines, is upended to a decentralized wastewater treatment system to convert black water into a useful resource for irrigating, flushing, construction etc. People participated in the decision making, the design, the construction and the maintenance plan. A maintenance fund is collected monthly from the household who are connected to the system (see fig. 24 and 25) (Capacity Re-port CUREINDIA, 2016).
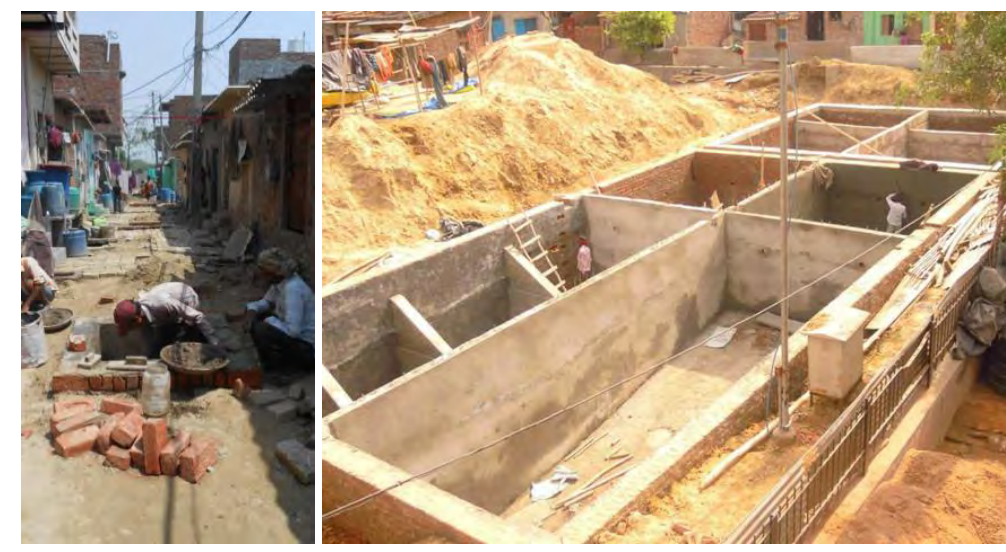

Fig. (24) and (25), Delhi, Savda Ghevra, Cluster Septic Tank and Simplified Sewer for Home Toilets Source: (CUREINDIA, 2016)

\section{Conclusion and Recommendations:}

This paper illustrates particular formal solutions presented by the Government of India to deal with the problem of slums. The paper explains the housing acts that deals with slums and housing solutions presented for the poor, with a special focus on the (PMAY) or "Housing for all" act. The paper shows several cases from several States and discusses several urban concepts; it shows also the role of the NGOs in the development of the slums and the enhancement of slums' in-habitants livelihood. 
Although the Indian formal solutions dealing with the slum bring an inspiring case study, this paper shows the risks and uncertainty in these solutions, they can be concluded as follows:

- 1.PMAY act which is taking place of JNNURM and RAY is dealing with dwellers residing on the slums prior to $1 / 1 / 2000$ leaving those who are settled after that date without any clear solutions, and it is too early to evaluate the promises to construct 20 million housing units. It is essential to find solutions for the slums formulated before 2000 .

- 2.As India a parliamentary republic with a multi-party system, Indian states/UTs are responsible to create their own housing policies; many states/UTs still without housing policies and need to formulate them soon ${ }^{23}$. Moreover, there is some delay in applying housing solutions when the national, State and local governments do not belong to the same political party, especially when the decision is shared between them.

- 3.Slums located in less valued lands still lack the interest of the private sectors for development, leaving the burden of responsibility for the States' public agencies for development. Moreover, many states/UTs Slums located on private land cannot be developed due to the share of land ownership between different owners.

- 4.Although FAR is used as a credit for the private developers in cities with high land price, it creates social problems and unbalanced openness to build spaces. The balance between land use and density should be taken into consideration, especially that the slums' dwellers are used to leave in low-rise buildings and very near from the land.

- 5.Location of the subsidized housing under PMAY, in most of the cities that were visited by the author, where located in the available public land in the periphery of these cities, this raises the question of livelihood when it will be inhabited. The solution for transportations, social and economic infrastructure should be found and provided immediately when these projects are completed.

- Following the PMAY verticals, States should develop Models to attract the private sector under the third vertical of the act "the affordable housing through PPP", Rajasthan and Gujarat have started initiatives to attract the private sector, Maharashtra is already advance in Mumbai, but on the other hands, other States need to be more effective and start their models and initiatives, especially when the land value is not high.

- When applying the land pooling policy, solutions for sharp rise of land prices across lands that fall under the purview of the policy should be found, as new landlords are created and the peasants remain poor. Such policy cannot be applied in other countries like Egypt, the change of the agriculture land to urban land is restricted and forbidden.

- The role of the NGOs is are essential in developing slums and enhancing the livelihood of the people, but the role of the NGOs should continue to guarantee the continuity of such initiatives, developing cadres from the locals is very important to the continuity of the projects. The Agakhan has applied that in their project, on the other hands more NGOs should be formulated to work in the slums.

\section{Acknowledgment:}

This paper was only possible to be written and completed because of experience and knowledge the author gained through the six weeks professional training program "Formal Solutions to Informal Settlements" conducted in India from $19^{\text {th }}$ September 2016 to $28^{\text {th }}$ October 2016 organized by the Human Settlement Management Institute (HSMI) under the International Technical \& Economic Cooperation program (ITEC) and fully sponsored by the Ministry of External Affairs, Government of India; an appreciation and a thank you go to the HSMI team, the Indian experts, professors and officials for their coordination, hospitality and fully support during my stay in India.

\section{References:}

1. Agakan. (2015), Nizamuddin Urban Renewal Initiative, annual report”, [Electronic version], Retrieved November 23, 2016, from 2015http://www.akdn.org/sites/akdn/files/media/publications/2015_annual_report__nizamuddin_urban_renewal_initiative.pdf

2. Ashar, S., (2014), Thane gets Mumbai's slum rehab model, Retrieved November 20, 2016, from http://indianexpress.com/article/cities/mumbai/thane-gets-mumbais-slum-rehab-model/

3. Census of India. (2011), Primary Census Abstract for Slum, 2011, Office of the Registrar General \& Census Commissioner, India, [Electronic version]. Retrieved November 15, 2016, from http:/www.censusindia.gov.in/2011-Documents/Slum-26-09-13.pdf

4. Centre for Urban and Regional Excellence (CUREINDIA) (2016b), Capacity report, [Electronic version]. Retrieved November 29, 2016, from https://issuu.com/cure06/docs/cure_-_capability_report_2016_6692bd373a184d/43?e=26663057/40470662

5. Centre for Urban and Regional Excellence (CUREINDIA). (2016a), Retrieved November 25, 2016, from http://cureindia.org/about-us/

6. Delhi Smart City (2016), Guidelines \& Features of New Land Pooling Policy, Retrieved November 20, 2016, from http://www.delhismartcities.com/land-pooling-policy/

\footnotetext{
${ }^{23}$ Indian States with housing policies are Punjab, Haryana, Maharashtra, Gujarat, Odisha, Rajasthan, Karnataka, Kerala, Madhya Pradesh, Telengana, Uttar Pradesh, other State are in the process of developing housing policies.
} 
7. Gill HS., (2016). India HABITAT - III National Report, a lecture presented to Human Settlement Management Institute, International Training Programme (ITEC/ SCAAP), for the international training program Formal Solutions to Informal Settlements on 25.10.2016

8. Government of India (2016), Unique Identification Authority of India, Retrieved October 20, 2016, from https://resident.uidai.net.in/home.

9. Govt. of Kerala, Town and country planning (2016), Why FAR is used? [Electronic version], Retrieved November 20, 2016, from http://www.townplanning.kerala.gov.in/pages/pdf/far.pdf

10. Human Development Index (HDI), (2015), [Electronic version], Retrieved November 15, 2016, from: http://hdr.undp.org/en/composite/HDI

11. INR (India National Report) for Habitat III. (2016), [Electronic ver-sion]. Retrieved November 15, 2016, from URL: mhupa.gov.in/writereaddata/1560.pdf

12. India Press Information Bureau. (2015), Extension of time for of Jawaharlal Nehru National Urban Renewal Mission. Retrieved November 30, 2016, from http://pib.nic.in/newsite/PrintRelease.aspx?relid=119916

13. IRX Live (2016), All you need to know about 'Land Pooling Policy, Retrieved October 20, 2016, from http://irxlive.com/faqs/all-you-need-toknow-about-land-pooling-policy.

14. Jain, A. K. (2016) Building twenty million homes, Housing for all, discovery publishing house PVT. LTD., India

15. JNNURM (Jawaharlal Nehru National Urban Renewal Mission) Government of India Ministry of Housing and Urban Poverty Alleviation. (2005), [Electronic version]. Retrieved November 30, 2016, from http://jnnurm.nic.in/wp-content/uploads/2011/01/PMSpeechOverviewE.pdf

16. Knoema. (2016) World GDP Ranking 2016. Retrieved November 15, 2016, from https://knoema.com/nwnfkne/world-gdp-ranking-2016-dataand-charts-forecast

17. Mahavir U., (2016). Pradhan Mantri Awas Yojana (PMAY) Housing for All, a Transitional Journey from RAY and JNNURM, a lecture presented to Human Settlement Management Institute, International Training Programme (ITEC/ SCAAP), for the international training program Formal Solutions to Informal Settlements on 29.09.2016

18. Naiknavare developers (2016), Slum Rehabilitation Projects. Retrieved October 20, 2016, from http://www.naiknavare.com/project-sraoverview.html

19. Narayan, S. and Singh, H., (2015), Pooling land, unlocking value, The India Press, [Electronic version], Retrieved November 18, 2016: http://indianexpress.com/article/india/india-others/pooling-land-unlocking-value/

20. NUHHP (National Urban Housing and Habitat policy) Government of India Ministry of Housing and Urban Poverty Alleviation. (2007), [Electronic version], Retrieved November 30, 2016, from: mhu-pa.gov.in/writereaddata/NUHHP_2007.pdf

21. Nagpal and Bureau (2015), Land Pooling Policy: All you want to know; The Economic Time, Retrieved December 9, 2016, from $\mathrm{http}$ //economictimes.indiatimes.com/wealth/personal-finance-news/land-pooling-policy-all-you-want-to-know/articleshow/46879596.cms

22. Negi, M., (2016). Urbanization:

23. Opportunities and Efforts, a lecture presented to Human Settlement Management Institute, International Training Programme (ITEC/ SCAAP), for the international training program Formal Solutions to Informal Settlements on 23.09.2016

24. PMAY (Pradhan Mantri Awas Yojana Housing for All) Government of India Ministry of Housing and Urban Poverty Alleviation. (2015), [Electronic version]. Retrieved November 15, 2016, from http://ud-hp.in/pdf/pmawasyojana.pdf

25. RAY (Rajiv Awas Yojana) Government of India Ministry of Housing and Urban Poverty Alleviation (2013). Guidelines for

26. Preparation of Slum Free City Plan of Action 2013 - 2022, Retrieved November 16, 2016, from http://mhupa.gov.in/writereaddata/RAYGuidelinesSFCP.pdf

27. Sabarmati River Front Development Corporation Ltd., (2016a), Re-connecting Ahmedabad to its River. Retrieved November 23, 2016, from http://www.sabarmatiriverfront.com/background

28. Sabarmati River Front Development Corporation Ltd., (2016b), Riverfront, socializing a River \& Inclusive Development, [Electronic version], Retrieved November 23, 2016, from: http://www.egovamc.com/SRFDCL/SRFDCL.pdf

29. Self Employed Women's Association (SEWA), Retrieved November 23, 2016, from http://www.sewa.org/About_Us.asp

30. Singh D., et al., (2013), Indian Housing Policy Landscape: sheltering from a gathering storm, ISET. Retrieved October 20, 2016 from: i-s-e-t.org/file download/131efed6-42f6-442d-a725-bac5da43a96d

31. SRA (Slum Rehabilitation Authority), (2016), Retrieved October 20, 2016, from http://www.sra.gov.in/pgeDRPInfo.aspx

32. UN-Habitat (2016), The New Urban Agenda, Retrieved October 20, 2016, from https://habitat3.org/the-new-urban-agenda/ 
Doaa Ahmed Shehata Abouelmagd / Proceedings of Science and Technolgy 